\title{
Potential Test Of Ethanol Extract From Onion (Allium Cepa L) Leaves As A Repellent To Aedes Aegypti
}

\author{
Basyar Adnani ${ }^{1}$, Zainabur Rahmah ${ }^{2}$, Avin Ainur Fitrianingsih ${ }^{3}$, Abdul Malik Setiawan ${ }^{3}$ \\ ${ }^{1}$ Medical Student of Faculty of Medicine and Health Sciences, Maulana Malik Ibrahim State Islamic University \\ of Malang \\ 2 Department of Parasitology, Faculty of Medicine and Health Sciences, Maulana Malik Ibrahim State Islamic \\ University of Malang \\ ${ }^{3}$ Department of Biomedical Science, Faculty of Medicine and Health Sciences, Maulana Malik Ibrahim State \\ Islamic University of Malang
}

\begin{tabular}{|c|c|}
\hline & $A b s t r a c t$ \\
\hline \begin{tabular}{ll}
\multicolumn{2}{l}{ Keyword : } \\
Aedes & aegypti; \\
onion & leaves; \\
repellent &
\end{tabular} & $\begin{array}{l}\text { Background : The most dangerous vector of mosquito-borne disease, } \\
\text { namely Dengue Haemorrhagic Fever (DHF), is Aedes aegypti. One of the } \\
\text { most commonly used prevention methods is using repellent. Objective: This } \\
\text { study aims to know red onion (Allium cepa L) leaves ability as a repellent } \\
\text { against mosquitoes bites, primarily Aedes aegypti. Onion leaves are known } \\
\text { to have flavonoids and essential oil content that believed to have health } \\
\text { benefits such as anti-inflammatory, insecticide, antifungal, and repellency } \\
\text { effects. Method: This study design was a post test only control group of true } \\
\text { experiment, with } \pm 300 \text { mosquitoes in five treatment groups. The study } \\
\text { design was a true experimental post-test only control group using } \pm 300 \\
\text { mosquitoes divided into five treatment groups. Positive control, negative } \\
\text { control, and three groups with each extract containing } 5 \%, 10 \% \text {, and } 20 \% \\
\text { content. The data taken is the number of mosquitoes alighted on attractants } \\
\text { available, for five consecutive days. The analytical test used is the Kruskal- } \\
\text { Walls and Spearman test with } \alpha \text { coefficient } 0.05 \text {. Results: the number of } \\
\text { mosquitoes perching on each of the extract treatment plates decreased with } \\
\text { increasing extract concentration. In the treatment control group, the negative } \\
\text { control had the highest number of mosquitoes perching, while the positive } \\
\text { control had the least number of perching mosquitoes. All concentrations of } \\
\text { ethanol extract, either } 10 \% \text {, } 15 \% \text {, or } 10 \% \text {, all have the effect of repellent } \\
\text { against Aedes aegypti. Conclusion : } 20 \% \text { of ethanol extract has the most } \\
\text { repellency effect on Aedes aegypti mosquitoes. }\end{array}$ \\
\hline
\end{tabular}

*Corresponding author

Email: dr.basyaradnani@gmail.com 


\section{INTRODUCTION}

Mosquitoes are the primary vector of various diseases dangerous to humans. The ability of mosquitoes to deliver disease agents and adapt to their environment, is one of the causes mosquitoes become vector that is difficult to avoid [1]. Some mosquitoes that transmit the disease to humans are Anopheles sp, Mansonia sp, Culex sp, and Aedes aegypti. Aedes aegypti is the vector of one of the deadliest disease caused by dengue virus infection (DENV), which is Dengue Hemorrhagic Fever (DHF).

The incidence of DHF has overgrown in the past few decades. The dengue virus (DENV) carried by Aedes aegypti mosquito poses a significant threat to public health. Research shows that around $2 / 5$ of the entire world population has a high risk of becoming infected with DENV [2]. There are reported 390 million dengue infections each year, with an estimated 3.9 billion people in 128 countries in the world who are at risk of being infected with dengue virus $[3,4]$.

Cases of DHF in Indonesia were first discovered in 1968, and since then, Indonesia is considered a hyperendemic nation for this disease. Indonesia became the second country with the most dengue cases in the world after Brazil in 2004-2010 [5]. In 2013, the Indonesian Ministry of Health reported that there were 112,511 cases of DHF in Indonesia (41.3 per 100,000 population), with the highest number of hospital admissions due to DHF in Southeast Asia, which was 1.6 out of 100 people each year [6].

The Government of Indonesia promotes programs to deal with dengue to reduce morbidity and mortality in families and communities [7]. One method used by the government is to do activities that protect humans from mosquito bites, such as the use of mosquito nets, the use of long clothes or trousers, and the use of repellent $[8,9]$. Repellent becomes one of Indonesia's most used methods to prevent insects from approaching and biting human or animal skin [10]. Repellent has also been proven to provide mosquito protection and has the properties of sticking to individuals, so that repellent users can do activities without having to be tied to a location [11]. Research on the use of repellent continues to be developed until a compound is known as the most effective repellent compound and is widely used by the wider community, namely N, N, diethyl-metatoluamide (DEET) [1].

DEET compounds are known to have a high level of effectiveness as a repellent in repelling mosquitoes. However, these compounds must be used with caution because they are toxic to the human body [10]. DEET can affect the human body from skin rashes, pruritus, muscle cramps, insomnia, and respiratory disorders to coma [12].

The continued use of DEET, which is balanced with incorrect dosages, can cause damage to the human body as mentioned above. Therefore, research needs to be conducted to find new repellents made from natural ingredients with consideration of safer, cheaper, environmentally friendly, also easily found and produced by the community $[13,14]$.

Natural materials that are often used as mosquito repellent are materials from plants, including ginger, black pepper, garlic bulbs, and onion bulbs [15]. Onion bulbs contain substances with a smell that are not liked by mosquitoes. Onion contains several chemical contents, such as essential oils, cycloalilin, metialilin, dihydroaliin and other compounds such as flavonoids, phenolics, terpenoids, anthocyanins, and amino acids. Onion becomes one of the recommended natural mosquito repellents because it does not interfere with the respiratory system, so it is safe to use [16,17].

Research on onion bulb extract conducted by Baskoro [16], shows that onion extract can function as a repellent. 
Supported by Kiu, et al. [18] which states that an onion bulb can be used as one of the natural repellents in repelling mosquitoes.

Research on the use of onion bulbs as mosquito repellent has been done, but no research has been conducted on how the potential of the extract of onion leaves (Allium cepa L.) as a repellent against mosquitoes. Onion leaves have a much lower price than the bulb and are known to contain flavonoids and essential oils in them.

Onion leaves are known to have higher flavonoid content compared to other plants [19]. Onion leaves are also thought to contain essential oils as their tubers do. Flavonoids have an insecticide, repellent, and antifungal effect on insects [20, 21]. While essential oils have health benefits such as anti-inflammatory, anti-buffer, antiinflammatory, antifungal, and decongestants [20, 22]. Therefore, researchers are interested in researching the potential of ethanol extract of onion leaves (Allium cepa L.) as a repellent against mosquitoes, which were tested on Aedes aegypti mosquitoes.

\section{MATERIALS AND METHODS \\ 2.1 Research Design}

This research was an experimental laboratory study with a true experimental post-test only control group design to determine and compare the effects of ethanol extract of red onion leaves (Allium cepa $L$ ) as a repellent against Aedes aegypti mosquitoes in various concentrations.

The factors involved in this research variable are as follows:

- The independent variable is the concentration and the duration of repellent exposure from onion leaf ethanol extract.

- The dependent variable is the number of mosquitoes that perched on each cup.

\subsection{Place and Time of the Study}

The study was conducted at the Entomology Department of the Parasitology Laboratory of the Faculty of
Medicine, Brawijaya University Malang, in January 2019, and the potential test was beginning between 06:00 and 13:00.

\subsection{Research Population}

The population used in this study was the Aedes aegypti sp., who met the researcher's inclusion and exclusion criteria. The inclusion criteria of this study are:

- Aedes aegypti sp. adult females

- Aedes aegypti sp. living adults

- Aedes aegypti sp. active adults

- Aedes aegypti sp. adults who have been fasted for at least 4 hours

The exclusion criteria of this study are:

- Adult male Aedes aegypti sp. mosquitoes

- Adult Aedes aegypti sp. mosquitoes that cannot fly

- Adult Aedes aegypti sp. mosquitoes which are not fasted of has been fasted but has not reached 4 hours

\subsection{Research Sample}

250 mosquitoes were used in this study. Mosquitoes then divided into 5 cages with 5 different treatments, as follow:

- Treatment I (Negative Control): A cup containing cotton, 2.5 cc chili marinade, and $2.5 \mathrm{cc}$ aquades.

- Treatment II (Positive Control): A cup containing cotton, 2.5 cc chili marinade, and $2.5 \mathrm{cc}$ DEET.

- Treatment III (Extract 10\%): A cup containing cotton, 2.5 cc chili marinade, and $2.5 \mathrm{cc}$ ethanol extract of onion leaves $10 \%$

- Treatment IV (Extract 10\%): A cup containing cotton, $2.5 \mathrm{cc}$ chili marinade, and $2.5 \mathrm{cc}$ ethanol extract of onion leaves $15 \%$

- Treatment V (Extract 10\%): A cup containing cotton, 2.5 cc chili marinade, and $2.5 \mathrm{cc}$ ethanol extract of onion leaves $20 \%$

The estimated number of repetition of this experiment is based on the formula calculation by Tjokronegoro [23] as follow: 


$$
\begin{gathered}
\mathbf{P}(\mathbf{n}-\mathbf{1}) \geq \mathbf{1 6} \\
\mathrm{P}=\text { number of treatment carried out } \\
\mathrm{n}=\text { number of repetition per treatment }
\end{gathered}
$$

Based on the formula above the calculation for repeated treatment is at least 5 times.

\subsection{Research Procedure}

\subsubsection{Data Collection Methods}

Observation forms were used to collect data. The number of mosquitoes that perch on the cup was counted and filled out to the form. The quantitative data was regarded as a ratio scale.

\subsubsection{Manufacture of Onion Leaves Extract}

The extraction process was carried out by ultrasound-assisted extraction using $96 \%$ ethanol solvent. The process is as follows:

- $500 \mathrm{~g}$ of Shallot Leaves are processed first into dry powder (simplicia) which is obtained from the Materia medika plant shop, Batu.

- The sample was then weighed with an analytical balance and dissolved using $96 \%$ ethanol in a beaker glass with a ratio of 1:10 simplicia and ethanol.

- The dissolved simplicia is then extracted by the UAE (ultrasonicassisted extraction) method using an ultrasonic cleaner for 3 x 2 minutes with a wavelength of $20-2000 \mathrm{~Hz}$ which will produce a top layer (supernatant) which is a mixture of ethanol and the active substance.

- The supernatant was filtered using filter paper so that filtrate was produced and collected into an evaporation flask.

- The results are then evaporated to separate the Shallot Leaves extract obtained from the ethanol solvent.

\subsubsection{Stock Extract Preparation Data Collection Methods}

A concentration of $100 \%$ onion leaves extract was used to make the stock solution. Following this, the stock solution was diluted using distilled water to make a concentration of $10 \%, 15 \%$, and $20 \%$ [14].

\subsubsection{Making Chili Water Immersion as Attractant}

As much as $1 / 2 \mathrm{~kg}$ of red chili blended until smooth, then add $500 \mathrm{ml}$ of water, put it in a closed bucket and leave for 7 days. After 7 days the results of the marinade can be used immediately.

\subsubsection{Repellent Potential Test}

Observations were made every 5 minutes at $0,1,2,4,6$ hours on mosquitoes perched on cotton in the cup. At each time interval between treatment hours, the cup is removed from the cage. The results are then recorded.

\subsubsection{Analysis of Results}

Data obtained from observation are then entered into a table and classified according to the treatment of this study. Due to abnormalities and inhomogeneity of the data, the analysis was conducted using non-parametric method. Analysis of the data used is the Kruskal Walls test using SPSS (Statistical Product Service Solution), followed by the Mann-Whitney test as a post hoc test to find out the potential differences between each treatment group. The data obtained also performed a Spearman correlation test to determine the relationship between the repellency potential and the length of treatment with the number of mosquitoes perched.

\section{RESULTS}

Result of this experiment shows that the average number of Aedes aegypti mosquitoes perched on treatment I (Negative control) was $8 \pm 3.03$, treatment II (Positive control) was $0 \pm 0$, treatment III $(10 \%)$ was $2 \pm 2.33$, treatment IV (15\%) was $1 \pm 1.50$, and treatment $\mathrm{V}(20 \%)$ was 1 \pm 1.68. Of the three non-control treatment groups, it was found that the concentration of $20 \%$ had the highest repellency effect compared to the other treatment groups. Detailed results can be seen in picture 1 .

3.1. Kruskal Walls Test on the Concentration Extract of Onion Leaves (Allium cepa $L$ ) to Mosquitoes Perched 
From the results of the analysis, it can be stated that there is a difference in the effectiveness of the concentration of extracts of onion leaves (Allium cepa $L$ ) as a repellent against Aedes aegypti mosquitoes. Statistically, this is proven by probability value $<\alpha(5 \%)$. Detailed results can be seen in table 1 .

Table 1: Kruskal Walls Test I

\begin{tabular}{cc}
\hline Chi-Square Statistic & Probability \\
\hline 84.263 & 0.000 \\
\hline
\end{tabular}

To find out where the significant differences are, a post hoc test is performed using Mann-Whitney test. The post hoc analysis results inform that the average number of Aedes aegypti mosquitoes that perched in the aquades treatment group was the most numerous and significantly different from the average number of Aedes aegypti mosquitoes in all treatments. While the number of Aedes aegypti mosquitoes in the treatment group given DEET was the lowest and significantly different from the average number of Aedes aegypti mosquitoes in all treatments. Detailed results can be seen in table 2 .

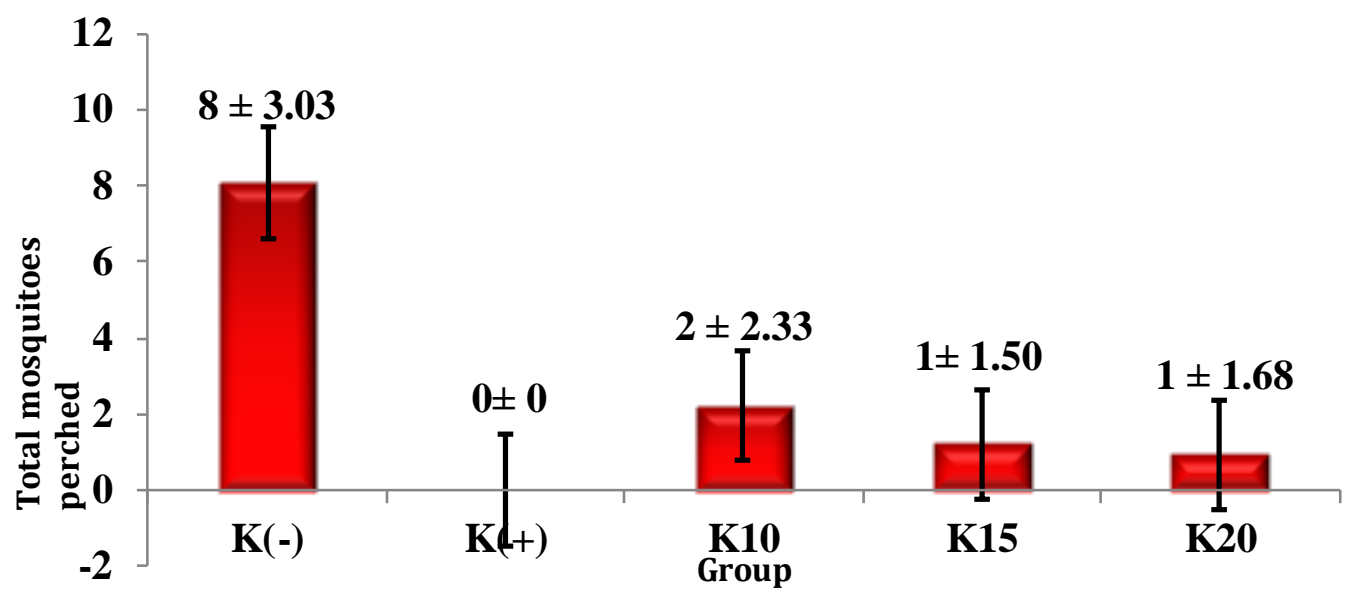

Note: K (-): negative control; K (+): positive control; K10: extract concentration of 10\%; K15: extract concentration of $15 \%$; K20: extract concentration of $20 \%$.

Picture 1. The Average Number of Aedes aegypti Mosquitoes that Perched Based on The Etanol Concentration of Onion Leaf (Allium cepa L) as Repellent

Table 2. Post Hoc Mann-Whitney Test 1

\begin{tabular}{cccccccc}
\hline & & \multicolumn{7}{c}{ Probability Pairwise Comparisons } \\
\cline { 3 - 8 } Waste & Mean & K(-) & K10 & K15 & K20 & K(+) & Notation \\
\hline K(-) & 8.08 & & 0.000 & 0.000 & 0.000 & 0.000 & $\mathrm{a}$ \\
\hline K10 & 2.20 & 0.000 & & 0.021 & 0.001 & 0.000 & $\mathrm{~b}$ \\
\hline K15 & 1.20 & 0.000 & 0.021 & & 0.155 & 0.000 & $\mathrm{c}$ \\
\hline K20 & 0.92 & 0.000 & 0.001 & 0.155 & & 0.000 & $\mathrm{c}$ \\
\hline K(+) & 0.00 & 0.000 & 0.000 & 0.000 & 0.000 & & $\mathrm{~d}$ \\
\hline
\end{tabular}


3.2. Kruskal Walls Test on the Length of Treatment of Onion Leaves (Allium cepa $L)$ to the Number of Mosquitoes Perched

The result of the analysis shown that there is no difference in the effectiveness of the concentration of extracts of onion leaves (Allium cepa L) on the length of the experiment as a repellent against Aedes aegypti mosquitoes as can be seen the probability value $>\alpha(5 \%)$. So there is no need to do a post hoc Mann-Whitney test in this Kruskal Walls test. The detailed result can be seen in table 3 .

Tabel 3: Kruskal Walls Test II

\begin{tabular}{cc}
\hline Chi-Square Statistic & Probability \\
\hline 4.976 & 0.290 \\
\hline
\end{tabular}

\subsection{Spearman Correlation Test on the} Concentration of Onion Leaves Extract (Allium cepa $L$ ) on the Number of Mosquitoes that Perched

Results of the test inform that there is a relationship between the level of concentrations of onion leaves extract (Allium cepa L) as a repellent with the amount of Aedes aegypti mosquito perched. The correlation test between the level of concentrations of onion leaves extract (Allium cepa $L$ ) as a repellent with the amount of Aedes aegypti mosquito perched shows that there is a negative (opposite) relationship which is quite strong. This is proven statistically with the probability value $<\alpha(5 \%)$ and the coefficient correlation value of -0.400 . Detailed results can be seen in table 4 .

Table 4: Spearman Correlation Test I

\begin{tabular}{cc}
\hline Correlation Coef. & Probability \\
\hline-0.400 & 0.000 \\
\hline
\end{tabular}

\subsection{Spearman Correlation Test on the} Length of Treatment of Onion Leaves (Allium cepa L) As a Repellent to the Number of Mosquitoes that Perched

The result of the test shows that there is a relationship between the length of treatment of onion leaves extract (Allium cepa $L$ ) as a repellent with the amount of
Aedes aegypti mosquito perched. The correlation test between the length of the experiment as a repellent and the amount of Aedes aegypti mosquitoes perched at proves that there is a positive (unidirectional) with the strength of the relationship is weak. These results are consistent with statistical analysis, which shows probability value $<\alpha$ $(5 \%)$ and the coefficient correlation value of 0.202 . Detailed results can be seen in table 5 .

Table 5: Spearman Correlation Test II

\begin{tabular}{cc}
\hline Correlation Coef. & Probability \\
\hline 0.202 & 0.044 \\
\hline
\end{tabular}

\section{DISCUSSION}

The concentrations used in this study start from $10 \%, 15 \%$, and $20 \%$ with the result that there is a significant adverse effect between the extract concentration and the number of attracted mosquitoes. It indicates that the higher the concentration used, the fewer mosquitoes perched on the cup. This condition indicates that the potential of substances as repellent is getting better because the more concentration is used, the higher the number of mosquitoes that reject it [24]. The result of data analysis is that there is a strong negative correlation, which also indicates that the greater the concentration used, the higher the content of the active substance in onion leaves extract (Allium cepa L), which can cause the Aedes aegypti mosquito to be reluctant to perch. So it can be concluded that the onion leaves extract has the potential as a repellent.

In the data analysis of the effect of the length of the experiment (persistence) on the number of mosquitoes perched, it was found that there was no significant difference from the average number of mosquitoes perched at each observation time. Nevertheless, the results of the study showed a positive relationship between the length of time (persistence) of the extract of onion leaves (Allium cepa L) as a repellent to the number of mosquitoes that perched. This indicates that the longer the use of the

Basyar Adnani, Zainabur Rahmah, Avin Ainur Fitrianingsih, Abdul Malik Setiawan 
onion leaves extract (Allium cepa L) as a repellent, the more mosquitoes perched. So it can be concluded that the longer the time of observation, the potential for onion leaves extract (Allium cepa $L$ ) as a repellent against Aedes aegypti mosquitoes will decrease.

This situation can be caused by the occurrence of evaporation from the extract over time, so that mosquitoes do not recognize the smell of substances contained in onion leaves (Allium cepa L) which causes it reluctant to perched to the attractants that have been provided. Younus, et al. [25] said that here also there is a strong role of ODE (Odor Degrading Enzyme) to eliminate the odor complex from repellent in $\mathrm{OBP}$ and make mosquitoes smell the attractant again. Also, the condition of the study environment can affect the behavior of mosquitoes during treatment. The intended environmental conditions can be caused by temperature, humidity, and wind gusts in the room. It is known that the temperature of $28^{\circ} \mathrm{C}$ is the optimum temperature in mosquito activity [26]. So there is a possibility that the mosquito's landing to the cup is influenced by the increased level of mosquito activity, plus the mosquito is placed in a cage with limited space.

Onion leaves (Allium cepa L) have been known to be one of the main sources of flavonoids in various countries. Although derived from similar biosynthetic pathways, onions accumulate different amounts of flavonoids in each plant tissue. Onion leaves are one part of a plant with a high flavonoid content, which is influenced by the stage of plant development and the environmental conditions in which shallots grow [27]. Flavonoids are one component of phenolic, which are compounds with $\mathrm{OH}$ groups attached to an aromatic ring, which are important and are used as insecticides and repellent in higher plants [28].

Flavonoids are one of the compound compounds in essential oils, and according to Guenther [29], compounds in volatile oils are volatile at room temperature. This indicates that the response to reject mosquitoes depends on the concentration and time of exposure because essential oils have volatile properties even more at room temperature [24]. Also, some essential oils have an effect as a repellent against insects. In previous studies, it was known that allycin and allyl methyl sulfide, which are the contents of essential oils, also affect as a repellent against mosquitoes [15].

In a previous study by Muhamat, et al. [30], it was supported that the essential oil content was an odorless compound which mosquitoes did not like and that this compound was found in several plants, including zodia, legundi, and onion leaves. It was also said the effect of essential oils as mosquito repellent on some plants varied when a study was carried out on several different mosquito species.

These odor compounds will bind to the chemoreceptors of the mosquito (sensilla), which are in the mosquito antenna and enter through the pores of the sensory trichodea [31]. The odor molecule will be carried by olfactory receptor neurons (ORNs) to the antenna lobes in the brain to be interpreted that the molecule is not an attractant molecule. Then the molecule will bind to odorant-binding proteins (OBPs) and interact with G-protein-coupled receptors in olfactory receptors (ORs). G-protein will be alternately active and cause changes in Gprotein conformation so that there is an activation of intracellular signals in the form of cyclic AMP and IP3 + DAG (cyclic adenosine monophosphate and inositol triphosphate diacylglycerol) which will open the pathway for $\mathrm{Na}++$ and $\mathrm{Ca}++$ ions. The entry of these two molecules causes depolarization of the mosquito's nerves and produces electrical impulses, which are then sent to the mosquito antenna lobes, and response arises in the form of appropriate behavior that is avoiding the odor [32].

Previous research on onion leaves used as a repellent against mosquitoes has never been done, but studies using other parts of the onion plant have been conducted. 
Kiu et al. [7] in their research concluded that an onion bulb could repel and even cause death in mosquitoes. Kumar, et al. [33] supported by Debra, et al. [34] also said that an onion bulb becomes one of the traditional plants that have an effect on health as an insect repellent (repellent) to avoid insect bites and scorpion stings.

The limitation of this study is that this study used extracted material without analysis and separation between the flavonoids on the onion leaves first so that no description of the active substances that played the most role and the determination of the flavonoid levels contained in the onion leaves. The concentrations tested still did not match the positive control (DEET), although the results showed that the onion leaves (Allium cepa $L$ ) had the potential to be natural repellent. Also, it is unknown side effects from the use of onion leaves as a repellent in humans. Therefore, further research is needed to determine the most effective concentrations and side effects that can occur in the use of onion leaves (Allium cepa $L$ ) to be used as a natural repellent option.

\section{CONCLUSIONS}

Based on this study, it can be concluded that ethanol extract of onion leaves (Allium cepa $L$ ) has potential as a repellent against Aedes aegypti mosquitoes with the ethanol extract of $20 \%$ as the most effective repellent during the experiment. This study also found that there is a significant effect of differences in the effectiveness of the concentration of red onion extract (Allium cepa $L$ ) as a repellent against Aedes aegypti mosquitoes. It should be noted that this study concludes that there is no significant effect of differences in the effectiveness of the concentration of red onion leaf extract (Allium cepa L) on the length of the experiment (persistence) as a repellent in Aedes aegypti mosquitoes.

Also, it was found that the higher the concentration of red onion leaves extract (Allium cepa L.), the higher the potential for repellent against Aedes aegypti mosquitoes.
It was also found that the longer the time interval of exposure, the potential for repellent against Aedes aegypti mosquitoes decreases.

\section{ACKNOWLEDGMENTS}

Researcher thank the Department of Medical Health, Faculty of Medicine and Health Science UIN Maulana Malik Ibrahim Malang for providing us support and input so that researchers can get the best results during this research.

This study has passed the ethical clearance test by the Medical Research Ethics Commission of Medical and Health Science Faculty, The Islamic State University Maulana Malik Ibrahim of Malang with certificate number 001/ EC/ KEPK-FKIK/ 2020.

\section{REFERENCES}

1. Norris, J. Edmund., Coats, R. Joel. 2017. Current and Future Repellent Technologies: The Potential of Spatial Repellents and Their Place in Mosquito-Borne Disease Control. International Journal of Enviromental Research and Public Health.

2. Guo C, Zhou Z, Wen Z, Liu Y, Zeng C, Xiao D, Ou M, Han Y, Huang S, Liu D, Ye X, Zou X, Wu J, Wang H, Zeng EY, Jing C and Yang G. 2017. Global Epidemiology of Dengue Outbreaks in 1990-2015: A Systematic Review and Meta-Analysis. Frontiers in Cellular and Infection Microbiology.

3. Bhatt, Samir., dkk. 2013. The Global Distribution and Burden of Dengue. Department of Health and Human Services USA United States of America.

4. Brady OJ, Gething PW, Bhatt S, Messina JP, Brownstein JS, dkk. 2012. Refining the Global Spatial Limits of Dengue Virus Transmission by Evidence-Based Consensus. PLoS Neglected Tropical Disease.

5. Maula, W. Ahmad., Fuad, Anis., Utarini, Adi. 2018. Ten-years Trend of 
Dengue Research in Indonesia and South-east Asian Countries: A Bibliometric Analysis. Global Health Action 2018 vol 11.

6. Tam CC, O'Driscoll M, Taurel A-F, Nealon J, Hadinegoro SR (2018) Geographic Variation in Dengue Seroprevalence and Force of Infection in The Urban Paediatric Population of Indonesia. PLoS Neglected Tropical Disease.

7. Kusriastuti, Rita., Sutomo, Sumengen. 2005. Evolution of Dengue Prevention and Control Programme in Indonesia. Dengue Bulletin Vol. 29.

8. Harapan., dkk. 2018. Knowledge, Attitude, and Practice Regarding Dengue Virus Infection Among Inhabitants of Aceh, Indonesia: A Cross-sectional Study. BMC Infectious Disease.

9. Rakhmani, N. Aidha., Limpanont, Yanin., Kaewkungwal, Jaranit., Okanurak, Kamolnetr. 2018. Factor Associated with Dengue Prevention Behaviour in Lowokwaru, Malang, Indonesia: a cross-sectional study. BMC Public Health.

10. Legeay, Samuel., Clere, Nicolas., Marchais, A. Veronique., Faure, Sebastien., Lapied, Bruno. 2018. Unusual modes of action of the repellent DEET in insects highlight some human side effects, European Journal of Pharmacology.

11. Gryseels, C., Uk, S., Sluydts, V., Durnez, L., Phoeuk, P., Suon, S., Set, S., Heng, S., Siv, S., Gerrets, R., Tho, S., Coosemans, M., \& Peeters Grietens, K. (2015). Factors influencing the use of topical repellents: implications for the effectiveness of malaria elimination strategies. Scientific reports, 5, 16847.

12. BPOM. 2014. Bahaya DEET pada Insect-Repellent., http://ik.pom.go.id /v2014/artikel/BahayaDEETpadaInsect .pdf. Badan Pengawasan Obat dan Makanan Indonesia.

13. Patel, E., Gupta, A., \& Oswal, R. (2012). Review On: Mosquito
Repellent Methods. International Journal of Pharmaceutical, Chemical and Biological Sciences. International Journal of Pharmaceutical.

14. Reegan, A.D., Gandhi, M.R., Paulraj, M.G. dan Ignacimuthu, S., 2015. Ovicidal and oviposition deterrent activities of medicinal plant extracts again Aedes Aegypti L. and Culex quinquefasciatus say mosquitoes. Osong Public health and research perspectives.

15. Upadhyay, R. K. (2016). Neuraceutical, Pharmaceutical and Therapeutic Uses of Allium cepa: A Review. International Journal of Green Pharmacy, 3-18.

16. Baskoro. 2011. Uji Potensi Ekstrak Etanol Bawang Merah (Allium cepa L) sebagai Penolak Hinggapan (Repellent) terhadap Nyamuk Culex sp dengan Metode Gelang Anti Nyamuk. Jurnal Penelitian Program Studi Pendidikan Dokter FKUB Universitas Brawijaya.

17. Ouyang, Hui., Hou, Kun., Peng, Wanxi., Liu, Zhenling., Deng, Heping. 2017. Antioxidant and Xanthine Oxidase Inhibitory Activities of Total Polyphenols from Onion. Saudi Journal of Biological Sciences.

18. Kiu, Hildawaty., Kadir, Sunarto., Saraswati, Dian. 2015. Ekstrak Bawang Merah dan Ekstrak Bawang Putih Sebagai Pengusir Nyamuk Culex sp yang Ramah Lingkungan. Artikel Penelitian Fakultas Ilmu-ilmu Kesehatan dan Keolahragaan Universitas Negeri Gorontalo.

19. Lanzotti, Virginia. 2006. The Analysis of Onion and Garlic. Journal of Chromatography A.

20. Fuadzy, H., \& Marina, R. (2012). Potensi Daun Dewa sebagai Larvasida Aedes Aegypti. ASPIRATOR-Journal of Vector Borne Disease Studies.

21. Meselhy, K.M. 2012. Cytotoxic and Insect-Repellent Activities of Surface Flavonoids from Datura Stramonium L. Grown in Egypt. Mesir: Life Science Journal, 9 (4), Hal. 3154-3158. 
22. Rusli, M.S. 2010. Sukses Memproduksi Minyak Atsiri. Jakarta: AgroMedia.

23. Tjokronegoro, 2004. Pengetahuan Praktis Melatih. Jakarta: Aksara Baru

24. Shinta. (2012). Potensi Minyak Atsiri Daun Nilam ((Pogostemon Cablin B.), Daun Babadotan (Ageratum Conyzoides L), Bunga Kenanga (Cananga Odorata Hook F \& Thoms) Dan Daun Rosemarry (Rosmarinus Officinalis L) Sebagai Repelan Terhadap Nyamuk Aedes Aegypti L. Media Litbang Kesehatan Volume 22 Nomor 2, 61-68.

25. Younus, F., Fraser, N. j., Coppin, C. W., Liu, J.-W., Correy, G. J., Chertemps, T., . . . Oakeshott, J. G. (2017). Molecular basis for the behavioral effects of the odorant degrading enzyme Esterase 6 in Drosophila. Scientific Reports, 1-12.

26. Boesri, H. (2011). Biologi dan Peranan Aedes albopictus (Skuse) 1894 sebagai Penular Penyakit. Aspirator Vol 3, 117-125.

27. Rodrigues, A. S., Simal-Gandara, J., Almeida, D. P., \& Perez-Gregorio, M. R. (2917). Onions: A Asource of Flavonoids. Intech Open Science Open Minds, 442-447.

28. Bekele, D. (2018). Review on Insectiidal and Repellent Activity of Plant Products for Malaria Mosquito Control. Biomedical Research and Reviews, 2-7.
29. Guenther, E. (2006). Minyak Atsiri Jilid I Diterjemahkan oleh S. Ketaren. Jakarta: UI Press.

30. Muhamat, Wahyuni, T., Rusmiati, \& Jumar. (2016). DAYA PROTEKSI MINYAK ATSIRI ZODIA (Euvodia suaveolens) DALAM BENTUK SPRAY TERHADAP TEMPAT HINGGAP NYAMUK Aedes aegypti L. DAN Culex quinquefasciatus. Prosiding Seminar Nasional Lahan Basah 2016, 1-5.

31. Hill, S. R., Ignell, R., \& Hansson, B. (2009). Characterization of Antennal Trichoid Sensilla from Female Southern House Mosquito, Culex quinquefasciatus Say. Chemical Senses.

32. Paluch, Gretchen., Bartholomay, Lyric., Coats, Joel. 2010. Mosquito repellents: a review of chemical structure diversity and olfaction. Pest Manag SCI Society of Chemical Industry. Pp 2-5

33. Kumar, K. P., Bhowmik, D., Chiranjib, Biswajit, \& Tiwari, P. (2010). Allium cepa: A Traditional Medicinal Herb and its Health Benefit. Journal of Chemical and Pharmaceutical Research, 2-9.

34. Debra, K. R., \& Mischeck, D. (2014). Onion (Allium cepa) and garlic (Allium sativum) as pest control intercrops in cabbage based intercrop systems in Zimbabwe. IOSR Journal of Agriculture and Vetenary Science, 1-5. 
Table 6. Research data

\begin{tabular}{cccccc}
\hline \multicolumn{7}{c}{ Negative Control } \\
\hline $\begin{array}{c}\text { Time } \\
(\mathrm{H})\end{array}$ & 0 & 1 & 2 & 4 & 6 \\
\hline $\mathrm{U} 1$ & 6 & 12 & 10 & 14 & 18 \\
\hline $\mathrm{U} 2$ & 8 & 8 & 6 & 7 & 7 \\
\hline $\mathrm{U} 3$ & 10 & 5 & 6 & 4 & 7 \\
\hline $\mathrm{U} 4$ & 6 & 10 & 6 & 8 & 7 \\
\hline $\mathrm{U} 5$ & 8 & 7 & 6 & 7 & 9 \\
\hline
\end{tabular}

\begin{tabular}{cccccc}
\hline \multicolumn{7}{c}{ Positive Control } \\
\hline Time $(\mathrm{H})$ & 0 & 1 & 2 & 4 & 6 \\
\hline $\mathrm{U} 1$ & 0 & 0 & 0 & 0 & 0 \\
\hline $\mathrm{U} 2$ & 0 & 0 & 0 & 0 & 0 \\
\hline $\mathrm{U} 3$ & 0 & 0 & 0 & 0 & 0 \\
\hline $\mathrm{U} 4$ & 0 & 0 & 0 & 0 & 0 \\
\hline $\mathrm{U} 5$ & 0 & 0 & 0 & 0 & 0 \\
\hline
\end{tabular}

\begin{tabular}{cccccc}
\hline \multicolumn{7}{c}{ Extract } & Concentration of $10 \%$ \\
\hline $\begin{array}{c}\text { Time } \\
(\mathrm{H})\end{array}$ & 0 & 1 & 2 & 4 & 6 \\
\hline $\mathrm{U} 1$ & 4 & 3 & 6 & 7 & 10 \\
\hline $\mathrm{U} 2$ & 2 & 1 & 1 & 2 & 2 \\
\hline $\mathrm{U} 3$ & 2 & 1 & 1 & 1 & 2 \\
\hline $\mathrm{U} 4$ & 0 & 0 & 1 & 1 & 2 \\
\hline $\mathrm{U} 5$ & 0 & 1 & 1 & 2 & 2 \\
\hline
\end{tabular}

\begin{tabular}{cccccc}
\hline & \multicolumn{5}{c}{ Extract } \\
\hline Time $(\mathrm{H})$ & 0 & 1 & 2 & 4 & 6 \\
\hline $\mathrm{U} 1$ & 2 & 1 & 3 & 5 & 6 \\
\hline $\mathrm{U} 2$ & 1 & 0 & 1 & 1 & 2 \\
\hline $\mathrm{U} 3$ & 0 & 0 & 1 & 0 & 1 \\
\hline $\mathrm{U} 4$ & 0 & 1 & 0 & 1 & 1 \\
\hline $\mathrm{U} 5$ & 0 & 0 & 1 & 1 & 1 \\
\hline
\end{tabular}

\begin{tabular}{cccccc}
\hline \multicolumn{7}{c}{ Extract } & Concentration of 20\% & \\
\hline $\begin{array}{c}\text { Time } \\
(\mathrm{H})\end{array}$ & 0 & 1 & 2 & 4 & 6 \\
\hline $\mathrm{U} 1$ & 1 & 1 & 2 & 5 & 7 \\
\hline $\mathrm{U} 2$ & 1 & 0 & 0 & 0 & 1 \\
\hline $\mathrm{U} 3$ & 0 & 0 & 2 & 0 & 0 \\
\hline $\mathrm{U} 4$ & 0 & 0 & 0 & 0 & 1 \\
\hline $\mathrm{U} 5$ & 0 & 0 & 0 & 1 & 1 \\
\hline
\end{tabular}

\begin{tabular}{cc}
\hline & Total Mosquito Perched \\
\hline Negative Control & 0 \\
\hline Positive Control & 202 \\
\hline Extract Concentration of $10 \%$ & 55 \\
\hline Extract Concentration of $15 \%$ & 30 \\
\hline Extract Concentration of $20 \%$ & 23 \\
\hline
\end{tabular}

The results of the study calculated by the total number of mosquitoes that perched in each treatment group. U1: repetition of the day 1; U2: repetition of the dav 2: U3: repetition of the dav 3: U4: repetition of the 